\title{
The ShearStress importance on the spatial distribution pattern of the invader Limnoperna fortunei in the Upper Paraná River Basin. - An assessment based on the Spatial Distribution Models
}

\author{
Mônica de Cássia Souza Campos ${ }^{1,3}$, Daniel Peifer ${ }^{1}$ \& Paulo de Tarso Castro ${ }^{2}$ \\ ${ }^{1}$ Centro de Inovação e Tecnologia SENAI, Campus CETEC, Instituto Senai de Tecnologia em Meio \\ Ambiente, Belo Horizonte, MG, Brazil. \\ ${ }^{2}$ Universidade Federal de Ouro Preto, Ouro Preto, MG, Brazil. \\ ${ }^{3}$ Corresponding author: Mônica de Cássia Souza Campos, Av. José Cândido da Silveira, 2000, Santa Inês, \\ CEP 31035-536, MG Brazil, e-mail:monica.cetec@gmail.com
}

CAMPOS, M.C.S., PEIFER, D., CASTRO, P.T. The ShearStress importance on the spatial distribution pattern of the invader Limnoperna fortunei in the Upper Paraná River Basin. - An assessment based on the Spatial Distribution Models. Biota Neotropica. 16(1): e20140164. http://dx.doi.org/10.1590/1676-0611BN-2014-0164

\begin{abstract}
The introduction of the golden mussel, Limnoperna fortunei (Dunker, 1857) in South America was related to the discharge of ballast water, with its first record in 1991 in the La Plata River estuary. Since then, the species is spreading throughout the continent, with several economic and ecological negative consequences. Aim: To model, in the headwaters of Parana River, the spatial distribution of $L$. fortunei and to understand the determinants of the current pattern of species distribution and the risk of invasion of areas not yet colonized. Methods: The ecological niche of L. fortunei was modeled using the algorithm MAXENT (Maximum Entropy Method) combined with records of occurrence of the bivalve, limnological data and the shear force measured by the index Hack (SL). The evaluation of the performance of different models was based on AUC (Area Under the Curve).The analysis of each variable's contribution to the responses of the models was made based on the Jackknife test, available in the Maxent program. The models were validated with real absence data collected between 2006 and 2007. Based on the limnological characterization of the area and on outputs of the models, this analysis sought to understand the contributing aspects to the current and potential spatial distribution and to verify the risk of invasion of environments not yet colonized by the species. Results/Conclusion: The limnological characterization showed that the ecological requirements for the species as, $\mathrm{pH}$, calcium, oxygen and chlorophyll $a$, were appropriate in both the connected stretches, invaded and noninvaded. Turbidity showed significant spatial differences which proved to be higher in environments with higher levels of Hack (SL), i.e. higher energy fluvial. In addition, the algorithm showed the importance of hydrodynamical aspects expressed by Hack index (SL) to the spatial distribution of species, since the models with the best performances were those that considered the Hack index (SL) as one of the environmental layers of the mussel's niche. All models indicated a high risk of invasion into the reservoir of São Simão.
\end{abstract}

Keywords: invasive species, biological invasions, niche modeling, Maxent, ecological requirements.

CAMPOS, M.C.S., PEIFER, D., CASTRO, P.T. Importância da força de cisalhamento no padrão de distribuição espacial do invasor Limnoperna fortunei na Bacia do Alto rio Paraná. - Uma avaliação com base em Modelos de Distribuição Espacial. Biota Neotropica. 16(1): e20140164. http://dx.doi.org/10.1590/ 1676-0611-BN-2014-0164

Resumo: A introdução do mexilhão dourado, Limnoperna fortunei (Dunker, 1857) na América do Sul esteve relacionada às descargas de água de lastro, com seu primeiro registro em 1991, no estuário do rio da Prata. Desde então a espécie vai adentrando o continente - com várias consequências negativas em âmbitos econômicos e ecológicos. Objetivo: modelar em escala local a distribuição espacial de L. fortunei buscando melhor entender os fatores determinantes do padrão atual de distribuição da espécie e estimar o risco de invasão de áreas ainda não colonizadas. Métodos: A modelagem do nicho de L. fortunei foi realizada por meio do algoritmo MAXENT (Maximum Entropy Method) aliado a registros de ocorrência do bivalve, à dados limnológicos e à força de cisalhamento medida pelo índice de Hack (SL). A avaliação do desempenho dos diferentes modelos foi feita com base na AUC (Área sob a Curva). A análise da contribuição isolada das diferentes variáveis para as respostas dos modelos foi feita com base no teste Jackknife disponível no programa Maxent. Os modelos gerados foram validados com dados reais de ausência coletados entre 2006 e 2007. Com base na caracterização limnológica da área e nas respostas geradas pelos modelos de distribuição potencial, buscou-se entender quais aspectos estariam 
contribuindo para a distribuição espacial atual e potencial e verificar o risco de invasão de ambientes ainda não colonizados pela espécie. Resultados/Conclusão: A caracterização limnológica mostrou que os requerimentos ecológicos para a espécie como $\mathrm{pH}$, cálcio, oxigênio e clorofila $a$ foram igualmente adequados entre trechos invadidos e não invadidos conectados. Diferenças espaciais significativas foram encontradas em relação à turbidez, que se mostrou mais elevada nos ambientes com maiores índices de Hack (SL), ou seja, com maior energia fluvial. $\mathrm{O}$ algoritmo utilizado mostrou a importância de aspectos hidrodinâmicos, expressos pelo índice de Hack (SL) na distribuição espacial da espécie, uma vez que, os modelos com melhor desempenho foram aqueles que consideraram o índice de Hack (SL) como uma das camadas ambientais na composição do nicho da espécie. Todos os modelos indicaram também o alto risco de invasão para o reservatório de São Simão.

Palavras-chave: espécies invasoras, invasões biológicas, modelagem de nicho ecológico, Maxent, requerimentos ecológicos.

\section{Introduction}

Exotic invasive species can cause the extinction of vulnerable native species, either by predation, competition, or even the alteration of the habitat. These modifications have been taking place globally (Morton 1997, Karatayev et al. 2007, Karatayev et al. 2008, EPA 2013) and will continue into the future (Ricciardi \& MacIsaac 2000), with predictable declines in biodiversity (Sala et al. 2000). Therefore, it is essential to understand the invasion process, predict its successes and effects on the new environment. This includes, among other aspects, the identification of the invading species and the evaluation of probable areas of invasion (Mack et al. 2000).

Knowledge of the environmental characteristics of a given region, together with records of the occurrence of a species, can be used to indicate a range of environmental factors which determine locations in which a species could maintain populations or not known as the ecological niche (Chase \& Leibold 2003). In general, potential distribution models can be considered as the adjustment of a function between the points of occurrence of a species and a multivariate group of environmental data (Phillips et al. 2006). However, an invading species must overcome some filters in order to settle in a new region (Power et al. 1992). These filters include: geographical barriers; the physical environment, which characterizes the target habitat and may constitute a more or less favorable environment to a certain invading species; the demographical resistance; and, finally, the biological filter, which can be defined by the competition and predation between previously settled species and invading species (Williamson 1996). The points of occurrence assumed in the modeling process represent areas in which the physical habitat conditions are favorable to the invading species. However, other areas with similar conditions must exist, where the presence of the species is halted by the existence of filters related to inter-specific interactions, the existence of geographical barriers, long distances, and also the non-existence of the species dispersion vector. For this reason, in order to the use potential distribution models it is necessary to take into account the distinctions between the sub-space for the conditions and the subspace for the resources (Soberón 2007). The available environmental data must represent the sub-space for the conditions only, rather than the species niche as a whole (see Hutchinson's (1957) concept).

Limnoperna fortunei (Dunker, 1857) - popularly known as the golden mussel, is a non-native species which is currently spreading unchecked in South America. It was introduced in 1991 on the Argentinian shore, close to the Rio de la Plata (Pastorino et al. 1993), by means of ballast water discharges (Darrigran \& Pastorino 1995). It is a freshwater bivalve originally from Chinese and Southeastern Asian rivers (Morton 1975), which has been causing considerable economic and environmental impact. The occurrence of $L$. fortunei from the southern part of South America to the headwaters of the upper Paraná River (Campos et al 2012) shows how much its spatial distribution has been expanding in Brazil since 1998. For this reason, a better prediction of the environment's potential to accept or avoid the establishment of $L$. fortunei on the basis of niche modeling is essential for developing prevention and control strategies.

Different studies involving the prediction of the spatial distribution of aquatic species have focused on distinct environmental characteristics at the regional or continental levels (Peterson 2001, Peterson \& Vieglais 2001, Drake and Bossenbroek 2004, Iguchi et al. 2004, Kluza \& McNyset 2005, Campos et al 2014). The first studies related to the generation of ecologic niche models for aquatic species (Strayer 1991, Iguchi et al. 2004, Drake and Bossenbroek 2004, Bossenbroek et al 2007 ) utilized environmental variables (environmental layers) restricted to global climatic environmental variables (e.g., rainfall and air temperature).

In the case of bivalve molluscs, variables such as temperature, $\mathrm{pH}$, concentration of calcium in the water, alkalinity, hardness, chlorophyll, granulometric characteristics of natural substrates or even the presence of artificial substrates for settlement may be very important for its establishment in a new environment (Hincks \& Mackie 1997 Claudi \& Mackie, 1994 Mac Mahon, 1996). Ramcharam et al. (1992) and Mellina \& Rasmussen (1994) used $\mathrm{pH}$ and dissolved calcium in niche modeling for aquatic species; Koutnik \& Padilla (1994) focused on geological information (especially rock types).

Among the studies of the L. fortunei potential distribution which considered limnological variables, two used data points, from field sampling, to evaluate the distribution of the mussel in the Upper Paraguay River basin in Brazil and in some rivers in North America (Oliveira et al, 2010a, 2010b).

None of these works, however, highlights the importance of the shear stress (Bathurst 1982) or shear strength (Christofoletti 1981) as one of the potential determining variables for the niche and the potential distribution of L. fortunei. Considering that this bivalve is an epifaunal species, that the attachment to hard substrates is by means of a byssus (Morton 1973), and that its planktonic larval stages are easily dragged by water currents, the hypothesis presented in this paper is that the competence of a river, here indicated by the shear strength, is an important factor in the composition of L. fortunei's ecological niche, influencing its establishment in a new environment and consequently determining its distribution. For the study area in the lower Paranaíba River basin, Campos et al. (2012) indicated several factors that would impose a certain "hydrodynamic stress" on larval stages and would contribute to slowing the establishment of the mollusc, thus making it difficult for the bivalve to 
overcome the geographic barrier represented by the São Simão hydroelectricity plant and to establish in the river segment upstream. To prove this hypothesis, we modeled the L. fortunei niche using the algorithm Maximum Entropy Method (Maxent), incorporating the shear strength of the aquatic environments as one of the environmental layers of the ecological niche of L. fortunei.

This paper uses a model of potential distribution of the species based on limnological data and validation with real data. From the evaluation of the best-case and worst-case scenarios, we sought to illustrate that the distribution pattern of the invasive bivalve in a river stretch of the Upper Paraná River basin may have been influenced by a hydraulic component that has been neglected in studies of this species' niche modeling.

\section{Material and Methods}

\section{Area of Study}

The region of study comprises the confluence of the Paranaíba and Grande Rivers, in the borders of the states of Minas Gerais, Goiás, Mato Grosso do Sul and São Paulo (Figure 1). This region is part of the headwaters of the Paraná River and its tributaries, which are geographically connected to watercourses of other very important Brazilian watersheds. The segment of the lower Paranaíba River, downstream from the Hidroeletric Powerplant of São Simão, which belongs to Cemig (Companhia de Energia de Minas Gerais - Electric Energy Company of Minas Gerais), corresponds to the initial portion of the Paraná-Tietê waterway, where vessels transporting grains represent the main dispersion mechanism of the invading mussel.

The records of the bivalve occurrence, as well as the physical-chemical data used for the construction of the environmental layers, were obtained in 12 field campaigns which took place between 2006 and 2007, encompassing the rainy and dry seasons, in the lower Paranaíba River. Even eight years late, it must be emphasized that the spatial distribution pattern was not drastically modified and until now, the mussel has not invaded the São Simão reservoir.

In general, the presence points were used to construct the ecological niche models while the absence points were helpful in validating the generated models.

When modelling invasive species it must be considered that invasives are not in equilibrium with their environment and niche quantification and transferability in space and time are limited (Gallien et al. 2012). For the purpose of this study, only records from the Brazilian invaded region were used. In the case of an invasive species like $L$. fortunei, the true potential range of occurrence may differ from the realized range because of dispersal limitation, competition or other factors, so that evaluating model performance is a complex task and the use of observed absences may be misleading (Elith et al 2006). For instance, true absences could be allocated in areas that are either unsuitable for the species, or that are suitable but currently do not host any population. In this way for the case of modelling the potential distribution of an invasive species the techniques that play down the importance of absence information may be better suited to estimation of the ecological and distributional potential of the species, whereas methods incorporating absence information more directly may be more suitable for estimating actual distributions of species (JimenezValverde et al 2011).

1.1 Occurrence points (presence). Six presence points of the species occurrence (Figure 1) were found within a sampling net with 21 points located upstream and downstream from the São Simão reservoir (Figure 1). According to Stockwell \& Peters (2002), who assessed the accuracy of predictive models generated by different algorithms by comparing them with the number of occurrence records, under a machine-learning methods, average success rate at predicting occurrence of a species at a location or accuracy was $90 \%$ within ten sample

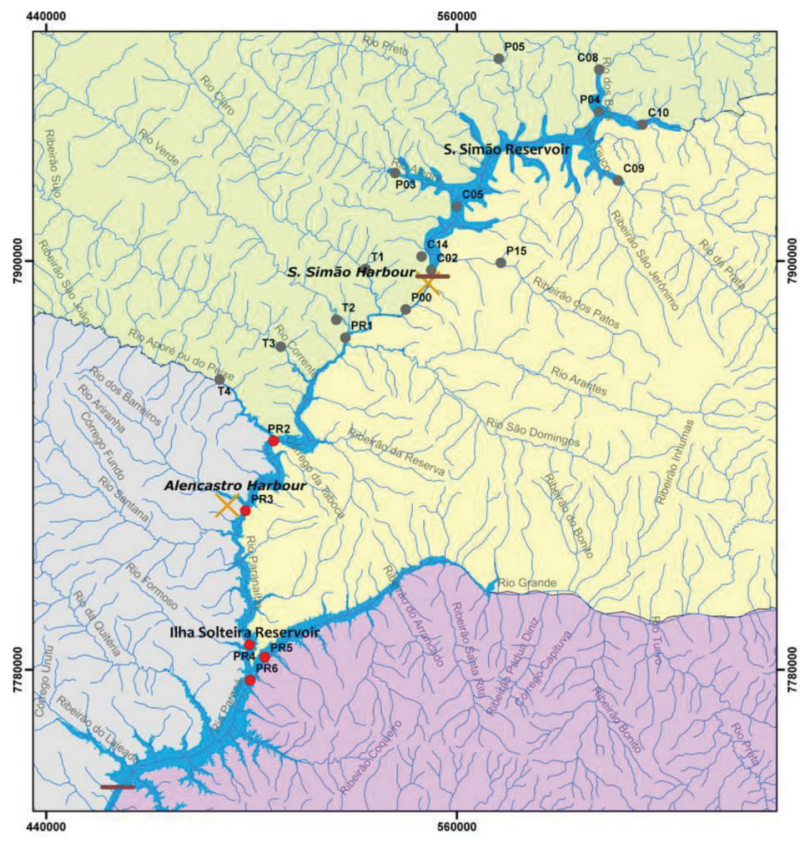

Spatial distribution of sampling poins
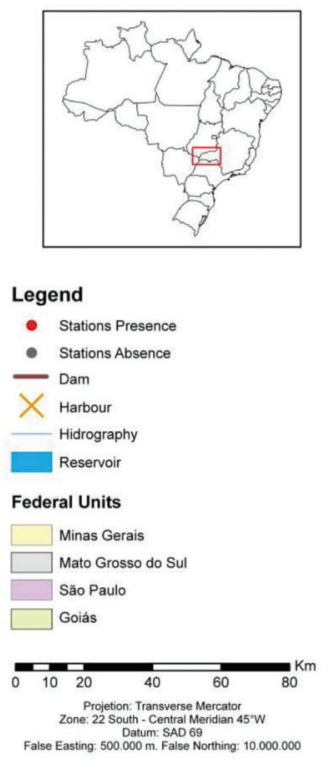

Figure 1. Sampling stations and golden mussel occurrence points along the Paranaíba River, upstream and downstream from the São Simão reservoir (MG/GO), Upper Paraná River Basin. 
points. So such a number of recorded presences represents a very satisfactory percentage for the purposes of this study.

1.2 Absence points. The species was not found in the São Simão reservoir and its affluents or in the tributaries of the Paranaíba River right margin - Claro (T1), Verde (T2), Corrente (T3) Rivers. In relation to the Aporé (T4) River, the invasive bivalve was found only in the confluence of the Aporé and Paranaíba Rivers (PR2), as it was showed in the Figure 1.

\section{Environmental Layers}

The choice of the environmental layers was based on the importance of the variables to the species' biology and its representability of the local heterogeneity (Table 1). As well, the correlation degree between the variables was evaluated to identify a possible collinearity among them. In this way, $\mathrm{pH} /$ dissolved oxygen / chlorophyll $a$ / turbidity / conductivity and calcium were considered as directly important to $L$. fortunei survival (Morton 1975, Ricciardi 1998, Sylvester et al. 2004, Karatayev et al. 2007, Pareschi et al. 2008). The spatial variation of the physical-chemical properties of water, chlorophyll $a$ concentrations and the $L$. fortunei density were assessed by applying a one-way ANOVA and the Tukeys method a posteriori or, a Kruskal-Wallis test for non-normal distribution cases with post-hoc comparisons of mean ranks of all pairs of group (Siegel \& Castellan 1988). The degree of correlation between the variables was tested using the non-parametric Spearman's correlation coefficient. Analyses were performed and graphed using STATISTIC 7 software (StatSoft South America, São Caetano do Sul - SP, Brazil).

For this study, an additional variable was chosen: the Hack Index or Stream Length-Gradient Index (SL), which expresses the energy of a fluvial environment and consequently its shear strength (Hack 1973, Etchebehere et al. 2004, Etchebehere et al. 2006).

The Hack Index is generally calculated using a topographic map and is mathematically defined as: $S L=\frac{\Delta H}{\Delta L} L$, where: $\mathrm{L}$ represents the length of the river segment, taken from its source (longest reach); $\Delta \mathrm{H}$ represents the altimetric variation, and $\Delta \mathrm{L}$ represents the horizontal distance - thus signifying the average declivity of the segment. From these empirical evidences (Hack 1957, Hack \& Young 1959), Hack observed that the river competence is proportional to the channel declivity (S) and the channel length (L) - an increase in size of the particles being deposited in the river channel corresponds to an increase in SL - in other words, the Hack Index (Hack 1973). Assuming that the competence of a river is directly related to its energy, it is understandable that the Hack Index (SL) should be taken as a measure or an indication of the river energy - and, therefore, as a comparative basis between them (Etchebehere et al. 2004, Etchebehere et al. 2006).

The environmental layers used in the simulation resulted from georeferencing the sampling points indicated in Figure 1, and from which abiotic data was obtained. From the spatial distribution of these points in a drainage network, interpolations of the spatial variation of limnological data were possible for segments with no punctual sampling. A total of 420 registers were used to create and to test the model. The points of confluence were taken into account in the calculation of the concentrations of abiotic constituents in river segments devoid of information. In these sites, there is a sudden increase in the discharge and sediment load transported by the river, making adjustments in the river physical-chemical characteristics necessary, in order to compensate for the perturbation of a previous state (Best 1986, Leopold \& Langbein 1964, Benda et al. 2004).The interpolation tools used were the Inverse Distance Weighting (IDW) and Kriging, these methods are available on the ArcGIS Spatial Analyst, version 9.

\section{Algorithm}

The software MAXENT version 3.2.1 (http://www.cs.princeton.edu/ schapire/maxent/) was used to model the L. fortunei ecological niche and ArcGis (version 9.3) was used to spatially represent the output data. The Software MAXENT - Maximum Entropy Method uses the maximum entropy principle, which states that the best approximation for an unknown probability distribution is the one that complies with any restriction to the distribution. This is a method used to make predictions or inferences using incomplete information (Phillips et al. 2006). The application of MAXENT to generate spatial distribution models results in the estimation of the probability of the species occurrence by finding the maximum entropy probability distribution submitted to a set of restrictions that represent the incomplete information on the target distribution.

The option "Auto features" was selected, using as output format the "Logistic" option - which offers an estimate between 0 and 1 for the probability of the presence of the species. $75 \%$ of the data was considered training points and was used to construct the model, and the remaining $25 \%$ was used as testing points, which are the points (data) used to assess the quality of the model.

From all possible combinations in the Maxent simulations, eight models of the golden mussel ecological niche were selected as representative of the extreme model performance situations - the best-case and worst-case scenarios of potential distribution. The eight chosen models, using different combinations of environmental layers, were: (1) all environmental layers; (2) all layers, excepting chlorophyll $a$; (3) all layers, excepting dissolved oxygen; (4) all layers, excepting the Hack Index (SL); (5) all layers, excepting dissolved oxygen / pH; (6) all layers, excepting dissolved oxygen / $\mathrm{pH} /$ calcium / conductivity; (7) all layers, excepting conductivity /pH / dissolved oxygen; (8) only the layers chlorophyll $a$ / SL.

The statistic method used to ascertain the model quality was the Area Under the Curve (AUC) calculated by Maxent software itself.

The evaluation of a model is based on the forecast performance and includes the determination of a minimum threshold of the quantitative value produced for the potential presence of a species. The sensibility of a model is defined as the proportion of true presences in relation to the total of presences predicted by the model. The specificity is defined as the ratio of true absences in relation to the total of absences predicted by the model. Thus, the Receiver Operating Characteristics (ROC) curve is obtained plotting the sensibility against 1 minus the specificity for different values of the probability threshold, generating an evaluation method of the threshold independent of the model (Manel et al. 2001). In addition, the area below the curve AUC is extensively used in species distribution modelling (SDM), characterizing the performance of the model, in all possible thresholds, based on a single value that can be used as an objective approach in comparing different models (Elith et al. 2006; Phillips et al. 
Importance of Shear Stress

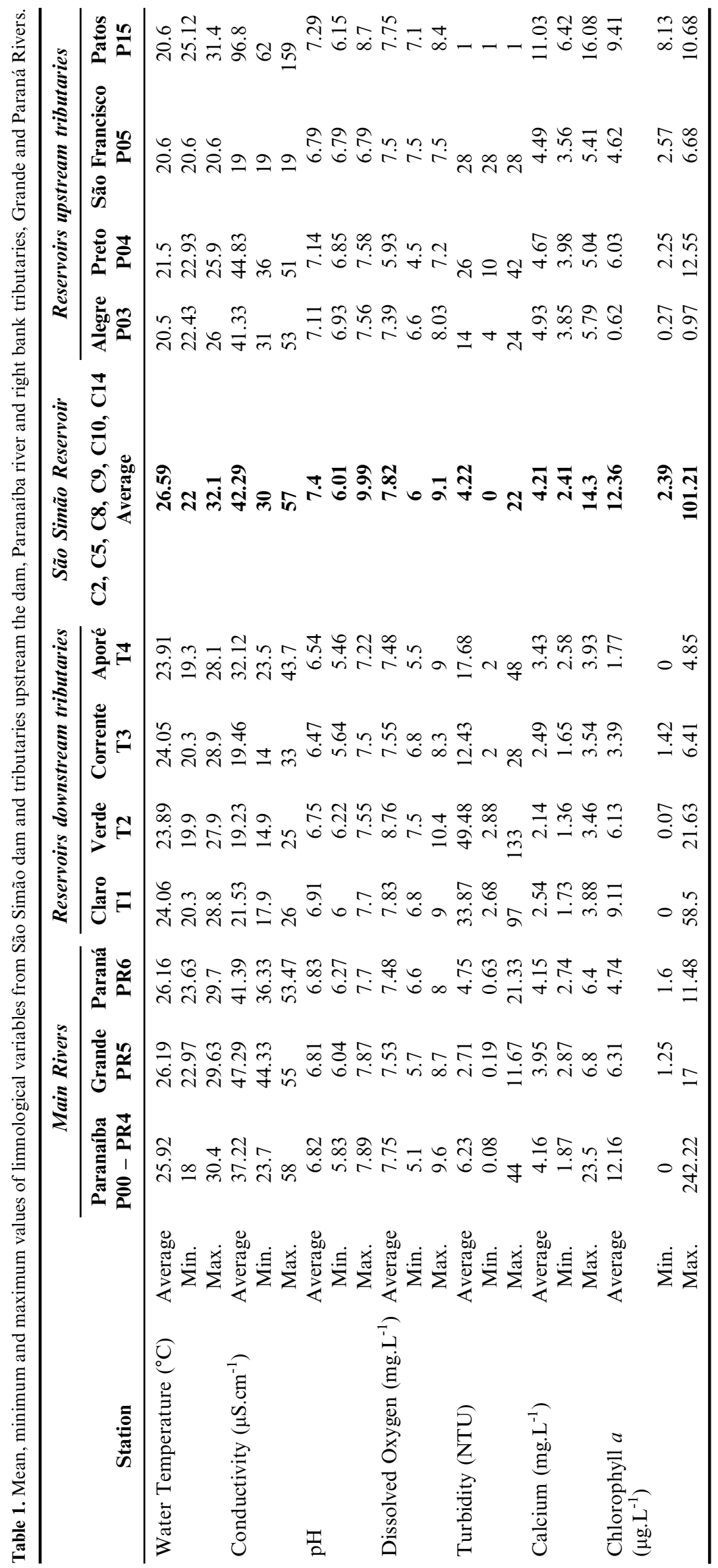


2006). The AUC varies from 0 to 1 , where 1 indicates high performance, while values lower than 0.5 indicate low performance (Luoto et al. 2005; Elith et al. 2006). In spite of recent criticisms (e.g., Lobo et al. 2008), AUC can still be useful comparing models of the same species in a similar geographical space. In this work, true records of absence were not considered, so the calculation of the AUC made use of the "background" data (also called pseudo-absences), chosen uniformly and randomly from the study area (Phillips et al 2006). Only the models that yielded an AUC value higher than 0.75 were considered in this study. Some measures were taken to minimize the limitations of the AUC as the use of true absences to validate the output scenarios and a good spatial distribution of the presence registers along of the study area.

Jackknife analysis was used to test the importance of the variables in the predictive ability of each model generated by Maxent.The Jackknife assessment excludes one variable at a time and recreates the model to determine the relative contribution of the predictor variable to the habitat suitability. It also considers each variable separately to determine whether it alone contributes significantly to the model.

\section{Results}

\subsection{Limnological characterization of the environments in $2006 / 2007$}

The average larval densities were low in the Paranaíba (that includes stations P00-PR4), Grande (PR5) and Paraná (PR6) rivers never exceeding 300 ind $\mathrm{m}^{-3}$. A longitudinal distribution gradient was noticed, which increased significantly between upstream and downstream, from the PR2 station on the Paranaíba River, to its confluence. A large density of golden mussel larvae was found at the PR3 station, on the Paranaíba River (Kruskal-Wallis test: $\mathrm{H}=58.69$ and $\mathrm{p}=0.0001)$ and downstream.

The surface waters yielded mean temperatures of $20-26^{\circ} \mathrm{C}$ with a range of $18.0-30.4^{\circ} \mathrm{C}$ (Table 1). The lowest average dissolved oxygen concentration corresponded to the tributaries located in the upstream portion of the dam of the hydroelectric plant of São Simão $(F=3.66$ and $p=0.013)$, although all environments present themselves well oxygenated, measuring always above the average value of $5.0 \mathrm{mg} . \mathrm{L}^{-1}$. In general the conductivity was low, but varied significantly between environments $(\mathrm{H}=94.80, \mathrm{p}=0.000)$. The average conductivity of the reservoir's downstream tributaries was smaller than that of the reservoir and its upstream tributaries. For the Paranaíba, Grande and Paraná Rivers, the average conductivity was between $37.22 \mu \mathrm{S} . \mathrm{cm}^{-1}$ and $47.29 \mu \mathrm{S} . \mathrm{cm}^{-1}$, measuring higher in the main rivers than in the downstream tributaries and lower than in the upstream tributaries of the São Simão reservoir. The maximum value recorded was $159 \mu \mathrm{S} . \mathrm{cm}^{-1}$ in the Patos River, where the presence of organic load was noticed.

The waters were more turbid in the upstream tributaries (average $=17.25$ NTUs) and downstream tributaries (28.37 NTUs) than in the others environments $(\mathrm{H}=36.17$ and $\mathrm{p}=0,000)$. The highest turbidity values were found in the Claro and Verde rivers, which correspond to typical lotic environments, with very expressive water speed and turbulence, resulting in high-energy segments (Figure 1). The turbidity in the São Simão reservoir and in the confluence of the Paranaíba, Grande and Paraníba Rivers was low ( $<6.23$ NTUs).
Chlorophyll $a$ concentrations in the study area were usually high, with mean values varying from 1.77 to $12.16 \mu \mathrm{g} . \mathrm{L}^{-1}$. Chlorophyll $a$ values were higher in the Paranaíba River than in its right-margin affluents, reaching a maximum of $242.22 \mu \mathrm{g} . \mathrm{L}^{-1}$, probably, due to blooms. The mean values in the Paranaíba River varied around $12.22 \mu \mathrm{g} . \mathrm{L}^{-1}$ and were close to the mean values obtained for the reservoir. In tributaries and other rivers, the chlorophyll concentrations were never higher than $10 \mu \mathrm{g} . \mathrm{L}^{-1}$. However, differences between means were not statistically significant. In general, the environments downstream from the reservoir were more acid than upstream, but these differences were not statistically significant. The lowest $\mathrm{pH}$ recorded was 5.83. The average calcium (Ca) values were around $4.1 \mathrm{mg} . \mathrm{L}^{-1}$ in the main rivers, the lowest being $1.8 \mathrm{mg} . \mathrm{L}^{-1}$ and the highest $23.5 \mathrm{mg} . \mathrm{L}^{-1}$. Mean Ca concentrations were lower in the downstream tributaries than in the Paranaíba, Grande and Paraná rivers $(\mathrm{F}=7,66$ and $\mathrm{p}=0,000)$. Ca concentrations were lower than $2.56 \mathrm{mg} . \mathrm{L}^{-1}$ in the Claro, Verde and Corrente tributaries and corresponded to $3.4 \mathrm{mg} . \mathrm{L}^{-1}$ in the Apore River. In the São Simão reservoir, the total mean $\mathrm{Ca}$ values were around $4.2 \mathrm{mg} . \mathrm{L}^{-1}$. The highest mean values were obtained from tributaries upstream from the reservoir, especially in the Patos River, where organic and industrial wastes are discharged.

In relation to the spatial distribution of the surface drainage energy (Figure 2), the segments of higher energy are the initial, lotic portion of the São Simão reservoir, its right-margin affluents (P03, P04 e P05) and the tributaries that flow to the Paranaíba River right margin, downstream from the reservoir (Claro River, T1, and Verde River, T2). The Paranaíba River channel is narrower and the water speed is higher up to station PR 1, being highly energetic in this portion. From this point on, the Hack Index (SL) progressively decreases, indicating the enlargement of the Paranaiba River flooding area, which includes the backwater of the Ilha Solteira Dam, located downstream the confluence of the Paraná and Paranaíba rivers.

\subsection{L. fortunei's potential distribution simulated by the MAXENT algorithm}

The parameters used to evaluate the models' performance, generated by MAXENT, are recorded in Table 2, where it is possible to see a greater similarity between the responses for models 1, 3, 4, 5, 6, and 7, with very close AUC values for the training points. In relation to testing points, there was greater variation, and again, the lowest values were obtained from models 2 and 8 .

Models 2 and 8 - which exclude SL and chlorophyll $a$ data respectively, were less accurate. Model 2 was the least efficient of all models, with AUC of 0.862 and 0.449 for training and testing points respectively, followed by model 8, which yielded AUC of 0.893 and 0.750 for training and testing points respectively.

Among the group of models considered more efficient, the spatial distribution generated by model 1 (Figure 3A) was chosen because it considered, simultaneously, all environmental variables ( $\mathrm{pH}$, dissolved oxygen, chlorophyll $a$, turbidity, conductivity, calcium and SL) although model 3 using a smaller number of variables and which has the same accuracy, could be preferable due to its simplicity. The model 1 showed that the areas which are the most sensitive to an $L$. fortunei invasion are the Paranaíba and Grande Rivers confluence, to nearly $80 \mathrm{~km}$ upstream, near the confluence with the Apore River (T4). This prediction was confirmed by the actual data of the presence of mussels collected 


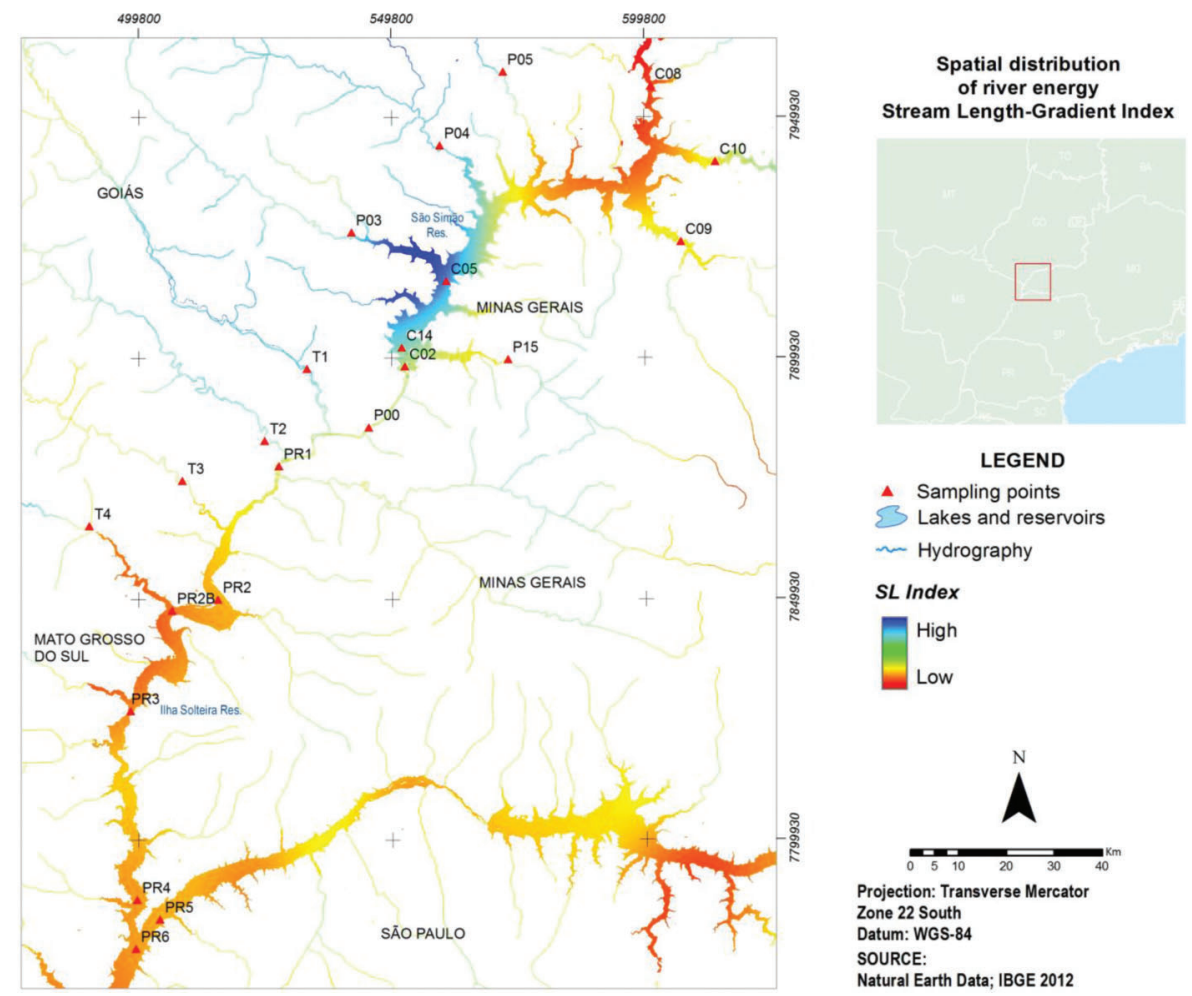

Figure 2. Spatial distribution of the surface drainage energy - from the Hack index - SL, interpolated by kriging.

for the same period. The reservoir area not yet invaded, corresponding to the stretches of points $\mathrm{C} 08$ and $\mathrm{C} 10$, was also considered highly vulnerable to invasion by the mussel. Other areas not colonized by the species showed a low risk of colonization: the Alegre, Preto and São Francisco Rivers (points P03, P04 and P05), upstream from the São Simão dam, or even rivers downstream of the reservoir, such as the Claro, Verde and Corrente Rivers (points T1, T2 and T3). In the Aporé River (T4) the invasion risk was medium and the probability of the species to occur tended to increase towards the confluence with the Paranaíba River, which is in accord with the records obtained in 2006 and 2007 and presented in Figure 1.

The L. fortunei potential distribution simulated by the MAXENT adopting model 1 showed a good adjustment with the observed data (Figure 3A): the areas where the probability of the mollusc occurrence is low in great part coincide spatially with the points of true absences confirmed by field checks.

In contrast, the spatial distribution simulated by model 2 showed that, when the variable SL is excluded from the niche modeling (Figure3B), most of the points where there are no records of the species corresponded spatially to areas of high probability of the mussel occurrence. These areas included not only the confluence of the Paranaíba and Grande rivers and the adjacent $80 \mathrm{~km}$ mentioned earlier, but also the whole segment from the "absence point" PR1 to the "absence point" C05 (including "absence points" P00, PB031, C02, C14, and C05) and the segments downstream from "absence points" $\mathrm{P} 15$ and P03; C08 and C10. Therefore, excluding SL from the list of variables that compose the $L$. fortunei niche, there was a clear decrease in the efficiency of the model to predict its real distribution area (AUC for training points is 0.862 and AUC for testing points is 0.449 ) and an inconsistency of simulated with actual absence data.

Figure 3C shows the potential distribution generated by model 8, which uses all environmental layers except chlorophyll $a$. The areas most vulnerable to an $L$. fortunei invasion were those which correspond to the segment from the mouth of the Paranaíba River to approximately $120 \mathrm{~km}$ upstream and

Table 2. Parameters to assess the accuracy of the models of potential distribution generated by Maxent

\begin{tabular}{lcc}
\hline (Model) / Environmental layers used in each model & AUC (training points) & AUC (testing points) \\
\hline (1) All layers & 0.917 & 0.896 \\
(2) Except SL & 0.862 & 0.449 \\
(3) Only Chlorophyll $a$ / SL & 0.916 & 0.899 \\
(4) Without layers OD / pH / Calcium / Conductivity & 0.918 & 0.917 \\
(5) Without layers OD / pH & 0.918 & 0.917 \\
(6) Except OD & 0.917 & 0.896 \\
(7) Without layers OD / pH / Conductivity & 0.918 & 0.917 \\
(8) Except Chlorophyll $a$ & 0.893 & 0.750 \\
\hline
\end{tabular}



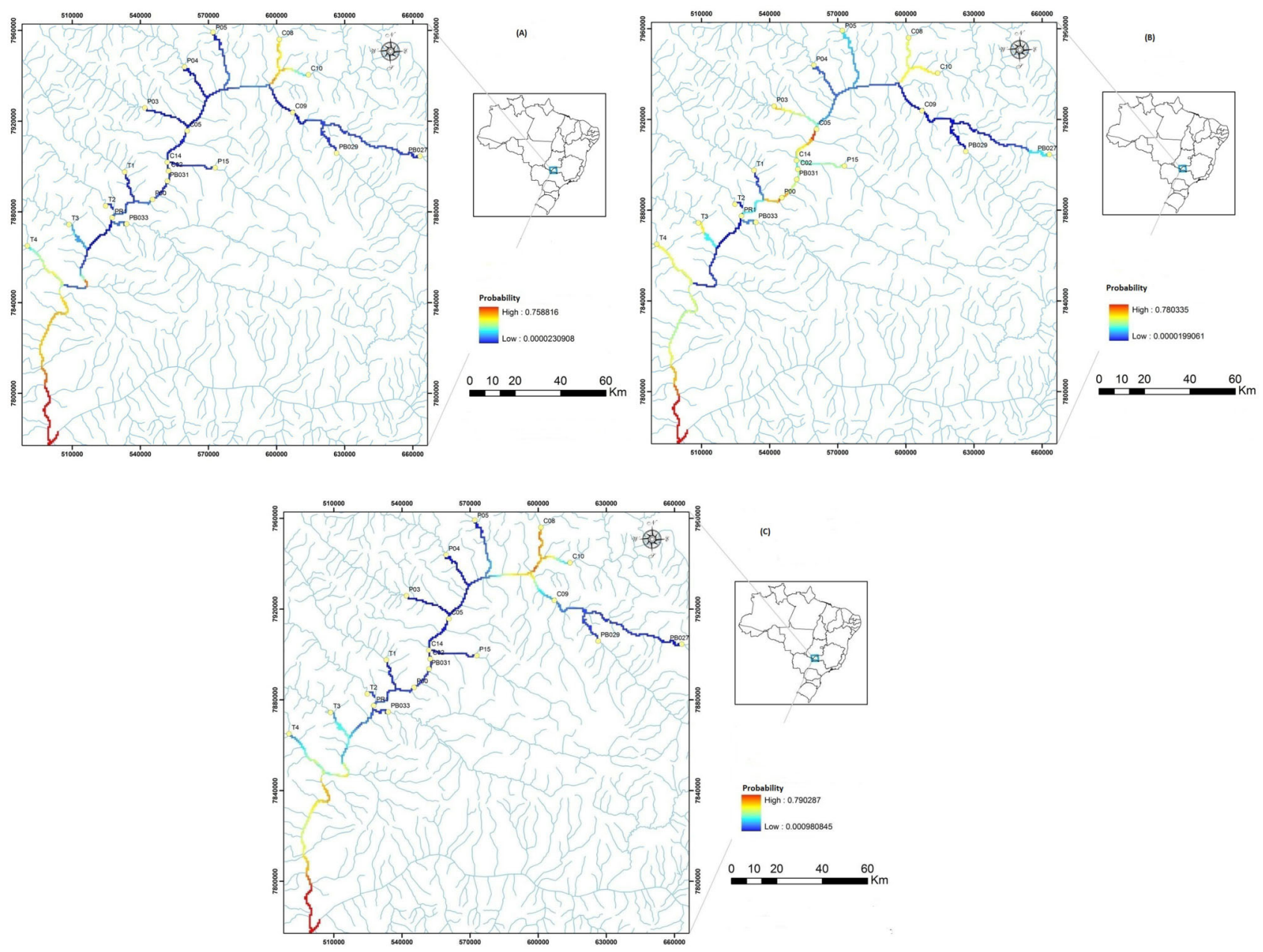

Figure 3A-C. L. fortunei potential distribution in the Upper Paraná River simulated by MAXENT, A) using pH, dissolved oxygen, chlorophyll $a$, turbidity, conductivity, calcium and SL data. B) using $\mathrm{pH}$, dissolved oxygen, chlorophyll $a$, turbidity, conductivity and calcium and excluding SL. C) using $\mathrm{pH}$, dissolved oxygen, SL, turbidity, conductivity and calcium and excluding chlorophyll $a$. For comparison, the yellow dots represent the absence of the golden mussel from 2006 to 2007.

segments downstream, including "absence points" T3 (Corrente River) and T4 (Verde River). The segment downstream from "absence points" $\mathrm{C} 08, \mathrm{C} 10$ and $\mathrm{C} 09$ was also prone to invasion. AUC for training points is 0.893 and for testing points is 0.750 . The exclusion of the chlorophyll $a$ variable led to a niche model with a better performance than model 2, which excluded SL, and a worse performance than model 1, which included all physical-chemical variables, in particular the hydrological variable SL.

The analysis of the results of the Jackknife test, which evaluates the isolated contribution of the environmental layers in the training and testing rounds of model 1 (Figure 4), shows that SL was the environmental layer that individually contributed the most for the construction of the niche model and for good evaluation (largest "gain"). From the training data, when the SL and chlorophyll $a$ variables were omitted, a decrease in the efficiency of the model was observed. A variable that decreases the efficiency of the model quality tests was $\mathrm{pH}$ (excluding $\mathrm{pH}$, the "gain" of the testing data was negative), whereas dissolved oxygen and conductivity did not seem to contribute or even to disturb the construction of the model. Calcium was less important when compared to the other variables (turbidity, chlorophyll $a$ and SL).

\section{Discussion}

In 2004, L. fortunei was detected in Porto Alencastro (PR3), located less than $120 \mathrm{~km}$ downstream from the São Simão reservoir (Campos et al. 2012). Considering that the speed of invasion upstream along the Rio de la Plata averaged $240 \mathrm{~km} /$ year (Darrigran \& Drago 2000), we can consider that the advance of the species is decelerated in this portion of the Paranaíba River, even with the continuous traffic of vessels that dock in the port downstream from the São Simão reservoir and bring the mussels attached to their hulls. Which factors could then explain the dissimilar L. fortunei occupation pattern in this segment of the river and in the reservoir - in other words, which factors are limiting the establishment of the mussel in these parts where it does not occur? According to Soberón \& Peterson (2005) and Soberón (2007), the establishment of an invading species is represented by the intersection of three components: adequate environmental conditions, favorable biotic interactions, and accessibility to the new region. Along the whole segment of the Paranaíba River downstream from the São Simão Reservoir, the lack of dispersion vectors from the colonized to the noncolonized areas could not be considered as a negative factor to the establishment of the golden mussel, considering the constant 
Importance of Shear Stress

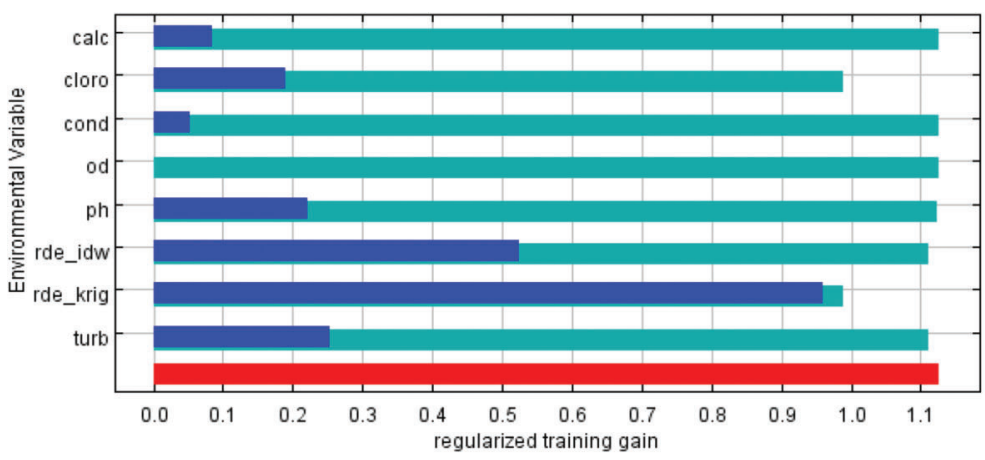

Without variable With only variable =

With all variables

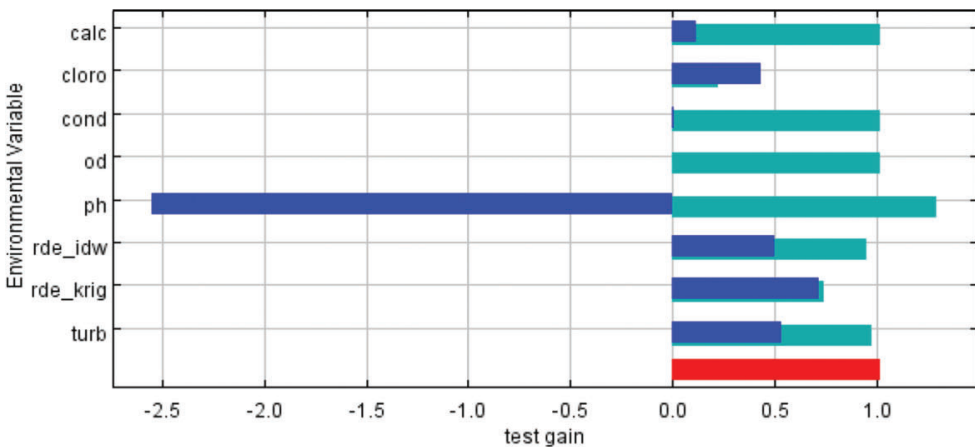

Without variable $=$ With only variable With all variables $=$

Figure 4. Results of Jackknife evaluations of relative importance of predictor variables (training data above and test below): $\mathrm{pH}$, dissolved oxygen (DO), chlorophyll $a$ (cloro), turbidity (turb), conductivity (cond), calcium (calc) and Rde_idw and Rde_krig ( note: different methods to interpolate the SL layer).

traffic of vessels coming from infested areas. A second filter relates to biological interactions, which were also considered less important, because in the areas further downstream from the same fluvial segment, the population densities of the invading bivalve are high, exceeding possible limitations regarding the availability of food or other negative interactions, such as parasites, competitors or even predators. Thus, unfavorable environmental conditions would be one of the most important filters in the conformation of the actual or potential spatial distributions.

Different physical-chemical aspects of the water were considered when generating niche models during this study (i.e., $\mathrm{pH}$, dissolved oxygen, calcium, conductivity, chlorophyll $a$ and turbidity), which have already been indicated by other researchers as determining factors for a causal relationship of the invading bivalve occurrence records (Oliveira et al 2010a, b). For instance,

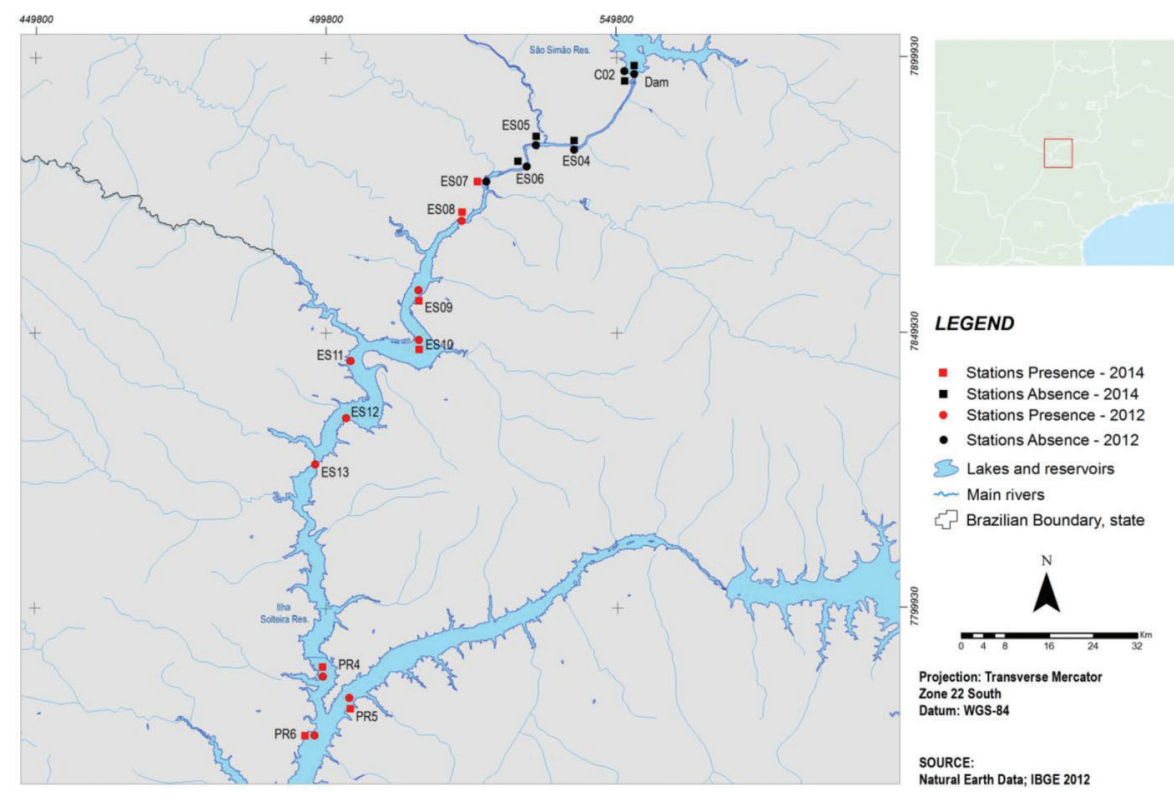

Figure 5. Golden mussel occurrence points along the Paranaíba River, upstream and downstream from the São Simão reservoir (MG/GO), Upper Paraná River Basin obtained during the period from 2012 to 2014. (data unpublished from ECOGERAES Consultoria Ambiental). 
some studies indicate a $\mathrm{pH}$ value $>5.0$ as favorable for the species survival (Ricciardi 1998, Montalto \& Marchese 2003, Karatayev et al. 2007). For calcium, minimum values for the survival of adult mussels in natural waters range between 1 and $3 \mathrm{mg} / \mathrm{L}$ (Ricciardi 1998).

Considering the limnological environmental characterization, the great part of variables presented similar and suitable average values to allow the survival of the mussel in the study area: oxygen values were generally high, and either the $\mathrm{pH}$ as the chlorophyll $a$ levels, for the great majority of the situations, would not constitute a limiting aspect to the species' survival. Just the turbidity and the calcium concentrations showed a significative spatial variation between invaded and uninvaded environments (Table 1). However, the lowest $\mathrm{Ca}$ concentration, found in one of the downstream tributaries, was close to $1.36 \mathrm{mg} . \mathrm{L}^{-1}$ meeting the minimum limits required for the species survival.

In turn, the highest values of turbidity occurred in the tributaries, upstream from the dam (P03, P04 e P05) or downstream (Claro River, T1, and Verde River, T2) and all of them corresponded to uninvaded river stretches as well as the segments of highest energy (high SL Index, high shear stress). Therefore, the aspects related to the energy and sediment transport of the fluvial environments appeared as the primary factors to explain the spatial heterogeneity and possible different levels of habitat suitability. In addition, differences in hydrodynamic aspects between invaded and uninvaded environments would be more relevant to determine the susceptibility to the establishment of the species than $\mathrm{pH}$, calcium, chlorophyll, and others (Neary \& Leach 1992, Ramcharam et al. 1992, Mellina \& Rasmussen 1994).

This trend also appeared in the simulations generated by MAXENT. Three clear patterns for the L. fortunei potential distribution models were obtained: (1) models generated with the inclusion of environmental layers SL and chlorophyll $a$ (independent from the other variables); (2) models generated excluding the environmental layer SL; (3) models generated excluding environmental layers SL and chlorophyll $a$.

The highest statistical accuracy values were obtained from models included in pattern (1) whose predictions coincided with the distribution of validation points. The models included in pattern (2) - models generated excluding environmental layer SL, yielded low statistical accuracy values in a broad sense (training and testing data), especially in the intermediate lotic portion, not coinciding with the points of real absence of the invading species. The models of pattern (3) - excluding SL and chlorophyll $a$, yielded the lowest statistical accuracy values and conflicted with the points of absence of the species.

These observations, plus the Jackknife analysis generated by MAXENT, led us to qualitatively rank the environmental layers according to their importance in predicting the potential distribution of L. fortunei in the lower Paranaíba River: SL > Chlorophyll $a>$ Turbidity $>$ Calcium $>$ Dissolved Oxygen $=$ Conductivity $>\mathrm{pH}$. Strictly speaking, SL was the variable that contributed the most to the efficiency of the constructed models.

Such ranking, allied to the environmental characterization, indicates that the shear strength (SL) or energy of the river waters could be the key factor related to the L. fortunei spatial distribution in the study area, while the other variables would be less influential in the golden mussel distribution, at least in the spatial scale considered.

A validation of these simulations results could also be done by observing the real spatial distribution of L. fortunei obtained later, from 2012 to 2014. As the Figure 5 shows, the most recent distribution area of the invasive mussel is quite similar to that simulated with data from 2006-2007. This indicates that the environmental conditions did not change expressively, and that the hydrodynamic is the key factor to force the spatial pattern until the present.

The importance of the hydrodynamic aspects for the environmental suitability of bivalve species has been pointed out in the literature. Clarke \& McMahon (1996) investigated the effect of the water speed on the production of byssus filaments in adult zebra mussels ( $D$. polymorpha), which are invading species with ecological characteristics similar to those of the golden mussel, and observed that the water flow eliminated the byssus production, which could be associated with the mechanical perturbation of the adhered mussels and influence on the ability to press the foot against the substrate to consolidate the filament. Another direct relationship can occur between the river energy and the strength to drag the planktonic larval stages, or the interference of the flow strength in larvae mortality. According to Horvath \& Lamberti (1999), zebra mussel veliger larvae seem to be highly susceptible to damage caused by physical strength such as shearing and consequently larvae mortality in turbulent flows could be an important mechanism to limit the dispersion of the zebra mussel downstream. The veliger larvae can be particularly sensitive to the breakage of the valves while feeding, because the valves must be open to allow food particles to enter the gills (Sprung 1993). An open shell can expose a larger surface and tissue area, being more susceptible to shearing.

The physical-chemical characteristics of the water in the region of the upper Paraná River - also the lower Paranaíba River - are generally adequate to the establishment of the invading species and therefore responded in a less important manner to the composition of the ecological niche models that best adjusted to the present spatial distribution of the species in the study area.

Furthermore, in its native area, the Pearl River (Zhujiang), L. fortunei is present in $\mathrm{pH}$ ranges of $6.9-8.4$ and calcium concentrations of $5.0-65.2 \mathrm{mg} . \mathrm{L}^{-1}$, (values taken in 75 hydrological stations in the Zhujiang for the period of 1958-2002, according Zhang et al. 2007). The limnological aspects from São Simão dam and tributaries upstream the dam, Paranaíba river and right bank tributaries, Grande and Paraná Rivers, when compared to the values of limnological variables from Pearl River, suggest that $L$. fortunei can withstand lower limits of $\mathrm{pH}$ and calcium than those for Asian environments. This information shows that the invaded niche is not contemplated in the native niche and indicates a greater invasiveness of this species and its potential area of dispersion.

On the other hand, the competence of the fluvial channels translated by the Hack Index proved to be an important component to describe the environmental suitability to the invading L. fortunei.

Although significance tests have not been done, all the best case scenarios correspond to models that include the hydrodynamic component. The result obtained in this study shows that, in similar future studies, the use of SL and other related hydrologic variables that have been neglected when modeling the L. fortunei niche should be taken into consideration. Should the use of SL be very complicated, it can be replaced by other variables that indicate the shear strength of the fluvial currents (flow, Reynolds number, etc.).

Despite the fact that the mussel has not established in the São Simão reservoir until now (2015), all the best models indicated the high risk level of invasion of this environment, with high 
degree of habitat suitability especially in some of its branches. Most likely, the invasion has not yet happened due to low pressure propagules (Campos et al 2012) that reach the reservoir. All these tools indicate that the invasion of this new environment will be a question of time and therefore, the intensification of preventive measures should be undertaken immediately.

\section{Acknowledgments}

This work was supported by the Electric Power Company of Minas Gerais - Cemig, the Agência Nacional de Energia Elétrica - ANEEL and the Program for Crustal Evolution and Natural Resources, Federal University of Ouro Preto, which granted a doctoral thesis, related to this work. The authors acknowledge Pedro Fialho for his assistance with the ARC GIS and two anonymous reviewers for their helpful suggestions.

\section{References}

ANDERSON, R.P., LEW, D. \& PETERSON, E.A.T. 2003. Evaluating predictive models of species' distributions: criteria for selecting optimal models. Ecol. Model. 162:211-232, http://dx.doi.org/ 10.1016/S0304-3800(02)00349-6.

BATHURST, J.C. 1982. Distribution of boundary shear stress in rivers. In Adjustments of the Fluvial System, D.D. (Rhodes and G.P Williams, eds.) Allen and Unwin, London, p. 95-116.

BENDA, L.N., POFF, L., MILLER, D., DUNNE, T., REEVES, G., PESS, G., \& POLLOCK, M. 2004. The network dynamic hypothesis: how channel networks structure riverine habitats. BioScience 54:413-427, http://dx.doi.org/10.1641/0006-3568(2004) 054[0413:TNDHHC]2.0.CO;2.

BEST, J.L. 1986. The morphology of river channel confluences. Progress in Physical Geography 10:157-174, http://dx.doi.org/10.1177/ 030913338601000201.

BOSSENBROEK, J.M., JOHNSON, L.E., PETERS, B. \& LODGE, D.M. 2007. Forecasting the expansion of zebra mussels in the United States. Conserv. Biol. 21:800-810, http://dx.doi.org/ 10.1111/j.1523-1739.2006.00614.x.

CAMPOS, M.C.S., ANDRADE A.F.A., KUNZMANN B., GALVÃO D.D., SILVA F.A., CARDOSO A.V., CARVALHO M.D., MOTA H.R. 2014. Modelling of the potential distribution of Limnoperna fortunei (Dunker, 1857) on a global scale. Aquatic Invasions 9:253-265, http://dx.doi.org/10.3391/ai.2014.9.3.03.

CAMPOS, M.C.S., LANZER R. \& CASTRO P.T. 2012. Hydrological stress as a limiting factor of the invasion of Limnoperna fortunei (Dunker, 1857) in the Upper Paraná River (Brazil). Acta Limnol. Brasil., 24 (1): 64-82, http://dx.doi.org/10.1590/S2179-975X2012005000027.

CHASE, J.M. \& LEIBOLD, M.A. 2003. Ecological Niches: Linking Classical and Contemporary Approaches. University of Chicago Press, Chicago.

CHRISTOFOLETTI, A. 1981. Geomorfologia fluvial: o canal fluvial. São Paulo: Edgard Blücher.

CLARK, M. \& McMAHON, R.F. 1996b. Effects of current velocity on byssal - threats production in the zebra mussel (Dreissena polymorpha) Can. J. Zool. v.74, p.63-69.

CLAUDI, R. \& MACKIE, G. 1994. Practical Manual for Zebra Mussel Monitoring and Control. Lewis Publishers.

DARRIGRAN, G. \& DRAGO, E. 2000. Distribucion de Limnoperna fortunei (Dunker, 1857) (Mytilidae), en la Cuenca del plata, Region Neotropical. Medio Ambiente 13(2):75-79.

DARRIGRAN, G. \& PASTORINO, G. 1995. The recent introduction of Asiatic Bivalve, Limnoperna fortunei (Mytilidae) into South America. The Veliger 38 (2):183-187.

DRAKE, J.M. \& BOSSENBROEK, E.J.M. 2004. The potential distribution of zebra mussels in the United States. BioScience 54:931-941, http:// dx.doi.org/10.1641/0006-3568(2004)054[0931:TPDOZM]2.0.CO;2.
EPA - United States Environmental Protection Agency. Water: Habitat Protection http://water.epa.gov/type/oceb/habitat/invasive_species_index.cfm last access at 10/15/2013.

ELITH J., GRAHAM C.H. 2006. Novel methods improve prediction of species' distributions from occurrence data. Ecography 29:129-151, http://dx.doi.org/10.1111/j.2006.0906-7590.04596.x.

ETCHEBEHERE, M.L.C., SAAD, A.R., SANTONI, G., CASADO, F.C. \& FULFARO, V.J. 2006. Deteç̧ão de prováveis deformações neotectônicas no vale do rio do Peixe, Região Ocidental Paulista, mediante aplicação de índices RDE (Relação Declividade-Extensão) em segmentos de drenagem. Revista UNESP - Geociências. 25(3):271-287.

ETCHEBEHERE, M.L.C., SAAD, A.R., PERINOTTO, J.A.J. \& FULFARO, V.J. 2004. Aplicação do Índice "Relação DeclividadeExtensão - RDE” na Bacia do Rio do Peixe (SP) para detecção de deformações neotectônicas, Revista do Instituto de Geociências da USP - Série Científica 4(2):43-56, http://dx.doi.org/10.5327/S1519874X2004000200004.

GALLIEN, L., DOUZET, R., PRATTE, S., ZIMMERMANN, N.E., \& THUILLER, W. 2012. Invasive species distribution models how violating the equilibrium assumption can create new insights. Global Ecol. Biogeogr 21:1126-1136, http://dx.doi.org/10.1111/ j.1466-8238.2012.00768.x.

HACK, J.T. 1957. Studies of longitudinal stream profiles in Virginia and Maryland. U.S. Geol. Survey Prof. Paper 294-B, p. 45-97.

HACK, J.T. \& YOUNG, R.S. 1959. Entrenched meanders of the North Fork of the Shenandoah River, Virginia. U.S. Geol. Survey Prof. Paper 354-A, $10 \mathrm{p}$.

HACK, J.T. 1973. Stream-profile analysis and stream-gradient index. J. Res. Us. Geol. 1(4):421-429.

HINCKS, S.S. \& MACKIE, G.L. 1997. Effects of pH, calcium, alkalinity, hardness, and chlorophyll on the survival, growth, and reproductive success of zebra mussel (Dreissena polymorpha) in Ontario lakes. Canadian Journal of Fisheries and Aquatic Sciences, Ottawa, 54:2049-57, http://dx.doi.org/10.1139/f97-114.

HORVATH, T.G. \& LAMBERTI, G.A. 1999. Mortality of zebra mussel, Dreissena polymorpha, veligersduring downstream transport. Fresh. Biol. 42:69-76, http://dx.doi.org/10.1046/j.1365-2427.1999.00462.x.

HUTCHINSON, G.E., 1957. Concluding remarks. Cold Spring Harb Symp Quant Biol 22:415-427.

IGUCHI, K., MATSUURA, K., MCNYSET, M., PETERSON, A.T., SCACHETTI-PEREIRA，R., POWERS, K., VIEGLAIS, D., WILEY, E.O. \& YODO, E.T. 2004. Predicting Invasions of North American Basses in Japan Using Native Range Data and a Genetic Algorithm. T. Am. Fish. Soc. 133:845-854.

KARATAYEV, A.Y., PADILLA, D.K., MINCHIN D., BOLTOVSKOY, D. \& BURLAKOVA, L. 2007. Changes in global economy and trade: the potential spread of exotic freshwater bivalves. Biol. Invasions 9:161-180, http://dx.doi.org/10.1007/s10530-006-9013-9.

KARATAYEV, A.Y., MASTITSKY, S.E., BURLAKOVA, L.E. \& OLENIN S. 2008. Past, current and future of the central European corridor for aquatic invasions in Belarus. Biol. Invasions 10:215232, http://dx.doi.org/10.1007/s10530-007-9124-y.

KOUTNIK, M.A., PADILLA, D.K. 1994. Predicting the spatial distribution of Dreissena polymorpha (zebra mussel) among inland lakes of Wisconsin: Modeling with a GIS. Can. J. Fish. Aquat. Sci. 51:1189-1196, http://dx.doi.org/10.1139/f94-118.

KLUZA, D.A. \& MCNYSET, M. 2005 Ecological niche modeling of aquatic invasive species. Aquatic Invaders 16(1):1-7.

LEOPOLD, L.B. \& LANGBEIN, W.B. 1964. Fluvial processes in geomorphology in San Francisco, W. H. Freeman.

LOBO, J.M., JIMÉNEZ-VALVERDE, A., REAL, R. 2008. AUC: A misleading measure of the performance of predictive distribution models. Global Ecology and Biogeography 17:145-151, http://dx.doi. org/10.1111/j.1466-8238.2007.00358.x.

LUOTO, M., POYRY J., HEIKKINEN R.K., SAARINEN K. 2005. Uncertainty of bioclimate envelope models based on the geographical distribution of species. Global Ecology and Biogeography 14:575-584, http://dx.doi.org/10.1111/j.1466-822X.2005.00186.x. 
MAC MAHON, R.F. 1996. The physiological ecology of the zebra mussel, Dreissena polymorpha, in North America and Europe. Am. Zool. 36:339-363.

MACK, R.N., SIMBERLOFF, D., LONSDALE, W.M., HARRY E., CLOUT, M., \& BAZZAZ F.A. 2000 Biotic Invasions: Causes, Epidemiology, Global Consequences, And Control, Ecol. Appl. 10 (3):689-710, http://dx.doi.org/10.1890/1051-0761(2000)010[0689: BICEGC]2.0.CO;2.

MANEL, S., WILLIAMS, H.C., ORMEROD, S.J. 2001. Evaluating presence-absence models in ecology: the need to account for prevalence. Journal of Applied Ecology 38:921-931, http://dx.doi.org/ 10.1046/j.1365-2664.2001.00647.x.

MCNYSET, K.M. 2005. Use of ecological niche modelling to predict distributions of freshwater fish species in Kansas. Ecol. Freshw. Fish. 14:243-255, http://dx.doi.org/10.1111/j.1600-0633.2005.00101.x.

MELLINA, E. \& RASMUSSEN, J.B. 1994. Patterns in the distribution and abundance of zebra mussel (Dreissena polymorpha) in rivers and lakes in relation to substrate and other physicochemical factors. Can. J. Fish. Aquat. Sci v. 51:1024-1036.

MONTALTO, L. \& MARCHESE, M. 2003. Limnoperna fortunei (Dunker, 1857) (Bivalvia, Mytilidae) tolerance to chlorine, $\mathrm{pH}$ and temperature in experimental conditions. Neotropica. 49:26-34.

MORTON, B. 1973. Some aspects of the biology and functional morphology of the organs of feeding and digestion of Limnoperna fortunei (Dunker) (Bivalvia: Mytilacea). Malacologia. 12:265-281.

MORTON, B. 1975. The colonization of Hong Kong's raw water supply system by Limnoperna fortunei (Dunker 1857) (Bivalvia: Mytilacea) from China. Malacological Review. 8(1-2):91-106.MORTON, B. 1997. The Aquatic nuisance species problem: a global perspective and review. In Zebra mussels and aquatic nuisance species, (F. M. D'Itri eds), Ann Arbor Press, Chelsea, MI Chp.1, p. 1-54.

NEARY, B.P. \& LEACH, J.H. 1992. Mapping the potential spread of the zebra mussel (Dreissena polymorpha) in Ontario. Can. Fish. and Aquat. Sci. 49:406-415, http://dx.doi.org/10.1139/F08-099.

OLIVEIRA, M.D., HAMILTON, S.K., CALHEIROS, D.F., JACOBI, C.M. \& LATINI, R.O. 2010a. Modeling the potential distribution of the invasive golden mussel Limnoperna fortunei in the Upper Paraguay River system using limnological variables, Braz. J. Biol. 70 (3): 831-840, http://dx.doi.org/10.1590/S1519-69842010000400014.

OLIVEIRA, M.D., HAMILTON, S.K. \& JACOBI, C.M., 2010b. Forecasting the expansion of the invasive golden mussel Limnoperna fortunei in Brazilian and North American rivers based on its occurrence in the Paraguay River and Pantanal wetland of Brazil. Aquatic Invasions 5:59-73.

PARESCHI, D.C., MATSUMURA-TUNDISI T., MEDEIROS G.R., LUIZA A.P. \& TUNDISI J.G. 2008. First occurrence of Limnoperna fortunei (Dunker, 1857) in the Rio Tietê watershed (São Paulo State, Brasil). Braz. J. Biol. 68(4):1107-1114.

PASTORINO, G., DARRIGRAN, G., MARTIN, S. \& LUNASCHI, L. 1993. Limnoperna fortunei (Dunker, 1857) (Mytilidae), nuevo bivalvo em águas del Rio de La Plata. Neotropica 39 (101-102):171.

PETERSON, A.T. \& VIEGLAIS, E.D.A. 2001. Predicting species invasions using ecological niche modeling: New approaches from bioinformatics attack a pressing problem. BioScience 51:363-371, http://dx.doi.org/10.1641/0006-3568(2001)051[0363:PSIUEN]2.0. $\mathrm{CO} ; 2$

PETERSON, A.T. 2001. Predicting species' geographic distributions based on ecological niche modeling. Condor 103:599-605, http:// dx.doi.org/10.1650/0010-5422(2001)103[0599:PSGDBO]2.0.CO;2.
PHILLIPS, S.J., ANDERSON, R.P. \& SCHAPIRE, R.E. 2006. Maximum entropy modeling of species geographic distributions Ecol. Model. 190:231-259, http://dx.doi.org/10.1016/j.ecolmodel.2005.03.026.

PHILLIPS, S.J., DUDIK, M. \& SCHAPIRE, R.E. 2004. A maximum entropy approach to species distribution modeling. In Proceedings of the 21st International Conference on Machine Learning, ACM Press, New York, p. 655-662, http://dx.doi.org/10.1145/1015330.1015412.

POWER, M.E., MARKS, J.C., PARKER \& E.M.S. 1992. Variation in the Vulnerability of Prey to Different Predators - CommunityLevel Consequences. Ecology. 73:2218-2223, http://dx.doi.org/ $10.2307 / 1941469$

RAMCHARAN, C.W., PADILLA, D.K. \& DODSON, S.I. 1992. Models to predict potential occurrence and density of the zebra mussel, Dreissena polymorpha. Can. J. Fish. Aquat. Sci. 49:26112620, http://dx.doi.org/10.1139/f92-289.

RICCIARDI, A. 1998. Global range expansion of the Asian mussel Limnoperna fortunei (Mytilidae): another fouling threat to freshwater systems. Biofouling, 13 (2):97-106, http://dx.doi.org/10.1080/ 08927019809378374.

RICCIARDI, A.H. \& MAC ISAAC, H. 2000. Recent mass invasion of the North American Great Lakes by Ponto-Caspian species. Trends Ecol. Evol. 15:62-65, http://dx.doi.org/10.1016/S0169-5347 (99)01745-0.

SALA, O.E., CHAPIN III, F.S., ARMESTO, J.J., BERLOW, E., BLOOMFIELD, J., DRZO, R., HUBER-SANWALD, E., HUENNEKE, L.F., JACKSON, R.B., KINZIG, A., LEEMANS, R., LODGE, D.M., MOONEY, OESTERHELD, M., POFF, N.L., SYKES, M.T., WALKER, B.H., WALKER, M. \& WALL, E.D.H. 2000. Global Biodiversity Scenarios for the Year 2100. Science, 287:1770-1774, http://dx.doi.org/10.1126/science.287.5459.1770.

SIEGEL, S. \& CASTELLAN N.J. 1988. Nonparametric statistics for the behavioral sciences. New York, NY: McGraw-Hill.

SOBERÓN, J. 2007. Grinnellian and Eltonian niches and geographic distributions of species. Ecology Letters, 10:1115-1123 doi: 10.1111/j.1461-0248.2007.01107.x, http://dx.doi.org/10.1111/j.14610248.2007.01107.x..

SOBERÓN, J. \& PETERSON A.T. 2005. Interpretation of models of fundamental ecological niches and speciesdistributional area. Biodivers Inf 2:1-10, http://dx.doi.org/10.17161/bi.v2i0.4.

SPRUNG, M. 1993. The other life: An account of present knowledge of the larval phase of Dreissena polymorpha. In Zebra mussels. Biology, impacts and control (T. F. Napela and D. W. Schloesser, eds.), Lewis Publishers, Boca Raton Chap. 2, p. 39-53.

STOCKWELL, D.R.B. \& PETERSON, A.T. 2002. Effects of sample size on accuracy of species distribution models. Ecol. Model. 148, 1-13, http://dx.doi.org/10.1016/S0304-3800(01)00388-X.

STRAYER, D.L. 1991. Projected distribution of the zebra mussel, Dreissena polymorpha, in North America. Can. J. Fish. Aquat. Sci. v.48 p.1389-1395, http://dx.doi.org/10.1139/cjfas-2015-0064.

SYLVESTER, F., DORADO, J., BOLTOVSKOY, D., JUÁREZ, A. \& CATALDO, D. 2004. Filtration rates of the invasive pest bivalve Limnoperna fortunei as a function of size and temperature. Hidrobiologia 534:71-80, http://dx.doi.org/10.1007/s10750-004-1322-3.

WILLIAMSON, M. 1996. Biological Invasions. Chapman and Hall, London.

ZHANG, S.R., LU, X.X., HIGGITT, D.L. et al. 2007.Water chemistry of the Zhujiang (Pearl River): natural processes and anthropogenic influences. J Geophys Res Earth Surf 112:1-17 123, http:// dx.doi.org/10.1029/2006JF000493. 